\title{
The Effectiveness of Decentralisation as a Response Mechanism for Disaster Risk Management in Bamenda, North West Cameroon
}

\author{
Ndi Roland Akoh \\ Department of Geography, Faculty of Arts, Letters and Social Sciences, The University of Yaounde I, Yaounde, Cameroon \\ Email address: \\ ndirolisonakoh@yahoo.com \\ To cite this article: \\ Ndi Roland Akoh. The Effectiveness of Decentralisation as a Response Mechanism for Disaster Risk Management in Bamenda, North West \\ Cameroon. Landscape Architecture and Regional Planning. Vol. 3, No. 2, 2018, pp. 51-63. doi: 10.11648/j.larp.20180302.15
}

Received: July 5, 2018; Accepted: July 17, 2018; Published: August 21, 2018

\begin{abstract}
Decentralized disaster risk governance has gained significant attention with the rising rate of global urban development today. Although scholarly debate/interest in this subject has grown, a comprehensive assessment of its efficiency is still rare. This paper attempts to fill this gap through a critical analysis of decentralisation as a response mechanism for disaster risk management in Bamenda in a bid to enshrine sustained solutions into concrete policy options. Using primary data (field observations, interviews, on-the-spot-appraisals) and secondary data (published/unpublished works and internet sources) sources through the descriptive and analytical methods of investigation, the findings unknots the fact that the intrinsic physical setting of Bamenda exhibited through its precarious geologic structure, undulating topography and extremely steep slopes are omni-inviting for a plethora of adverse environmental imprints. Contrary to these challenges, the urban development process in Bamenda has disregarded its natural setting as unplanned development through the anthropisation of slopes and wetlands is a common idiosyncrasy. Given this current state of affairs, however, the effectiveness of decentralization as a response mechanism for disaster risk management leaves much to be desired. This missing link is beset and partly catalyzed by deep institutional and regulatory lapses in the manifestation of decentralisation, ineffective and inconsistent management capacities, poor policy implementation and enforcement mechanisms relating to town planning instruments, bureaucracy and clientelistic practices. These speed breaks have rendered decentralisation as a response mechanism for disaster risk management largely ineffective in Bamenda. The paper suggests the need for the fortification of the capacities of workers in decentralized institutions, the need for the central government to devolve effective powers to local governments for disaster risk management, the need for greater financial autonomy and for the introduction of checks and balances to prevent the misuse of powers to achieve personal gains.
\end{abstract}

Keywords: Decentralisation, Effectiveness, Governance, Risk, Management, Bamenda

\section{Introduction}

Decentralization is the assignment of administrative, political and fiscal responsibilities to lower levels of government. In other words, decentralization is the transfer of power and resources from the central government to local citizens that gives them inter-a-lia, an opportunity to formulate and implement their own development programmes [1]. It is thus the restructuring or reorganization of authority so that there is a system of co-responsibility between institutions of governance at the central, regional and local levels according to the principle of subsidiarity [1]. Decentralisation can create opportunities for citizens to participate in governance processes from which they were excluded in more centralized systems [2]. This increases the overall quality and effectiveness of the governance system, while increasing the authority and capacities at sub-national levels [2]. Decentralization occurred as a political reaction to the failures of over-centralized political systems. Although there seems to be an ambiguous linkage between decentralisation and urban development, it is commonly 
agreed that decentralized local governance contributes to development in terms of promoting participatory development strategies and the production of policies that are adapted to local needs [3] as rapid urbanisation and development goes along with increasing disaster risks [4] and this trend is expected to continue in the coming decades [5]. The devolution of decision-making powers over natural resources to publicly accountable local authorities is frequently advocated as a means of achieving social development and the enhancement of environmental management [6]. Considering that disaster management is part of providing public safety services, one can expect a positive relationship between effective disaster management and decentralization [7].

According to the [8], there exist a number of factors that contribute to the configuration of risk in cities. First, history is important; for example where cities have been founded in or expanded into hazardous locations. Second, the urbanisation process leads to the concentration of populations in risk-prone locations within cities. As a result, populations expand faster than the capacity of urban authorities to supply housing or basic infrastructure, risk in informal settlements can accumulate quickly. Third, in cities with migrant populations, social and economic networks tend to be loose. As a result, people, especially minority groups of low social status become socially excluded forcing them to make difficult location decisions. That is why living in risk/hazardous locations is sometimes 'chosen' [8]. Based on this, it is but a truism that disaster risk is intimately connected to the processes of urban development as disasters triggered by natural hazards put development gains at risk. According to [9] and [10], risk is a function of Hazard, Vulnerability and Capacity: Risk $(\mathrm{R})=\operatorname{Hazard}(\mathrm{H}) \mathrm{x}$ Vulnerability (V)/Capacity (C).

Disaster risk is "the potential loss of life, injury, or damaged assets which could occur to a system, society or a community in a specific period of time, determined probabilistically as a function of hazard, exposure, and capacity [9]. In the technical sense, it is defined through the combination of these three terms, hazard, exposure and vulnerability. Until recently, however, development debates on decentralization largely focused on governance and efficiency and hardly on disaster risk management (the systematic process of using administrative decisions, organization, operational skills and capacities to implement policies, strategies and coping capacities of the society and communities to lessen the impacts of natural hazards and related environmental and technological disasters), the main research lacuna that this paper intends to fill.
Despite the efforts of various government to reduce disaster risks through decentralized local governance, successes recorded have been rather minimal as the constant occurrence of environmental hazards leaves much to be desired. It is, therefore, indispensable and expedient to lay bare the barrage of challenges borne by decentralization in a bid to configure appropriate modalities en route to sustainable disaster risk management. Based on this, an important questions to ask is: How does the natural environmental setting of Bamenda act as a passageway for disaster risks? Does decentralization promote participation of grassroots and improved governance as a tool for disaster risk reduction/management? The paper thus establishes the relationship between environmental powers, participation, accountability and outcomes by explaining the effectiveness of decentralization as a tool for disaster risk management. The main hypothesis that this thus paper addresses is that disaster risk is not inevitable, but on the contrary, can be managed and reduced through appropriate development policy and actions (decentralization in this context).

\section{The Study Area}

Bamenda is located between longitudes $10^{\circ} 09^{\prime \prime}$ and $10^{\circ}$ $11 "$ East of the Greenwich Meridian and between latitudes $5^{\circ}$ $56^{\prime \prime} \mathrm{N}$ and $5^{\circ} 58^{\prime \prime}$ North of the Equator (Figure 1). Bamenda gained the status of a city on the strength of a Presidential Decree of January $17^{\text {th }} 2008$ which created the Bamenda City Council from the defunct Bamenda Urban Council [7]. This was followed with the balkanization of Bamenda into three municipalities; Bamenda I (Mendankwe), Bamenda II (Mankon) and Bamenda III (Nkwen). The location of Bamenda along the Cameroon Volcanic Line (CVL) is a major disaster risk factor because hydro-geomorphic hazards (floods and landslides) are common. The town is implanted on two well distinct environments; the High Lava Plateau (Up Station) and the Low Plateau (Down-Town). These two plateau surfaces are separated by a broad escarpment commonly called the 'Bamenda escarpment'.

According to [12], the Bamenda escarpment zone is one of the most hazardous zones along the North-West stretch of the CVL. Increasing rates of urbanization and urban development have, however, forced people especially the poor to construct houses on this escarpment without recourse to urban planning regulations [11]. These victims, many of whom are poor and vulnerable, have occupied marginal and suburban areas, some of which are risk prone environments $([13 ; 14])$. 


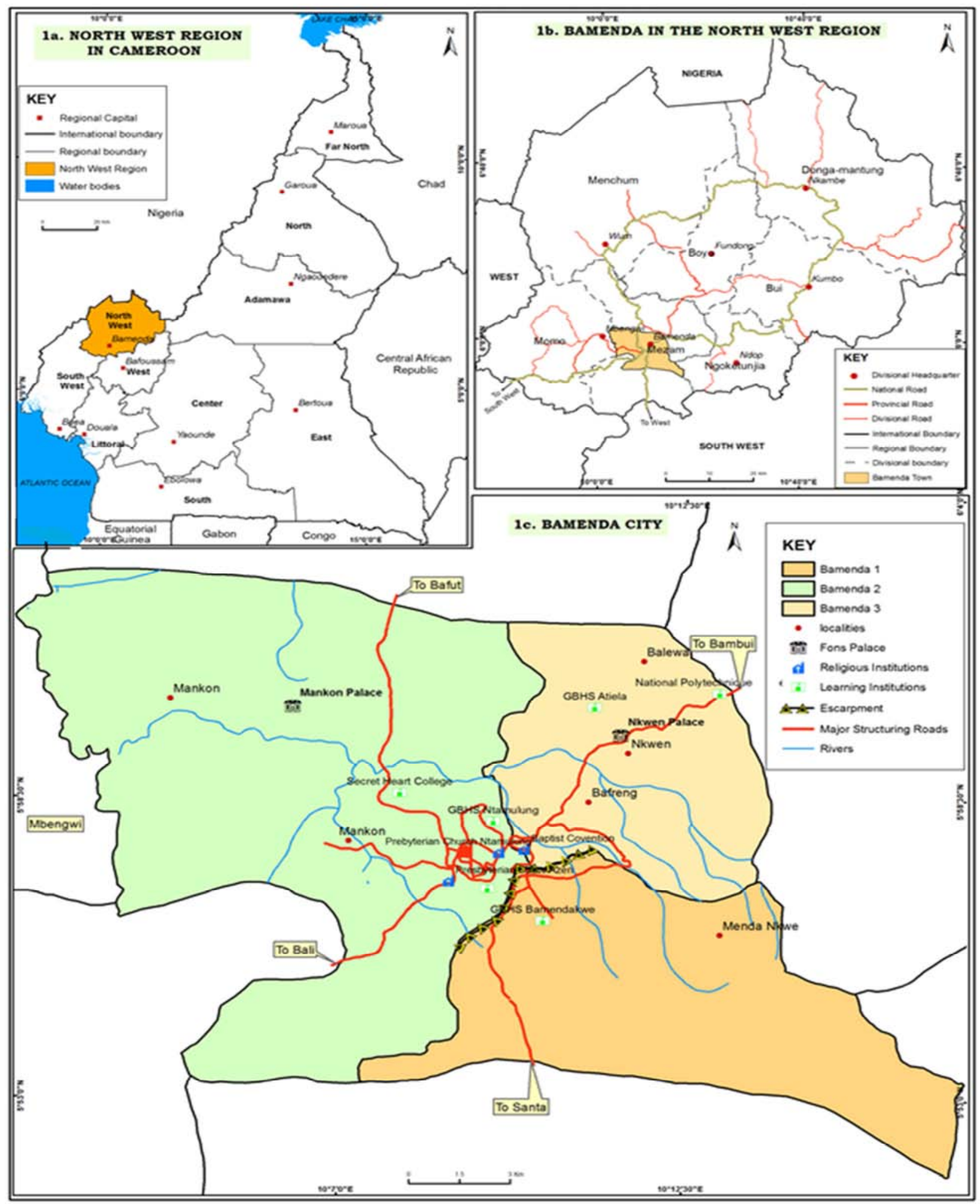

Source: Bamenda City Council (2018)

Figure 1. Location of Bamenda in Cameroon and the North West Region.

\section{Methodology}

The delineation of zones prone to disaster risks (landslides and floods) for the production of a combined landslide and flood hazard zonation map was done with the aid of the Global Positioning System device (G.P.S). Every feature recorded by the GPS was registered in the corresponding way point forms designed for the field work. All faulty features not well recorded with the GPS were regeoreferenced. The data was processed with one of the most 
widely used GIS software-arc view 9.1. The land use, hydrology, relief, slope and geologic maps of Bamenda aided in the process. Using these sources, therefore, a map showing the spatial distribution of zones prone to disaster risk in Bamenda was produced. This map could be used as a tool to help identify those areas which could be affected by a damaging landslide and floods as well as assessing their probability of occurrence over time. Primary data were further sought through questionnaires administration, field observations, interviews, focus group discussions (FGDs), on-the-spot-appraisals and impromptu discussions. Questionaires were administered to inhabitants of neighbourhoods prone to disaster risks and were done through systematic random sampling. These questionaires probed into the awareness of the existence of decentralization as a tool for urban space management well as its effectiveness as a response mechanism for disaster risk management. Interviews were conducted with local experts like policy makers and city planners saddled with the responsibilities of managing disaster risks (the Director of urban Development in the BCC, the Mayors of the three different Municipalities that make up the Bamenda urban space, the Regional Delegates of the Ministry of Housing and Urban Development as well as their respective Divisional and Sub Divisional Delegates. The data collected were analyzed and presented by employing descriptive statistic methods like tables percentages and even maps. In order to have a broad understanding of the issue of concern within a theoretical framework, secondary data were sources were gleaned from published and unpublished literature, internet sources as well as the existing decentralization laws of Cameroon.

\section{Results and Discussions}

The peculiarity of the geo-physical setting of Bamenda in terms of its relief, topography, geology, geologic structure (the nature of the bed rock) and the degree of slope have intrinsic/inherent traits that have in synergy influenced the type, pattern and magnitude of disaster risks like floods and landslides and thus the level of sustainability of development.

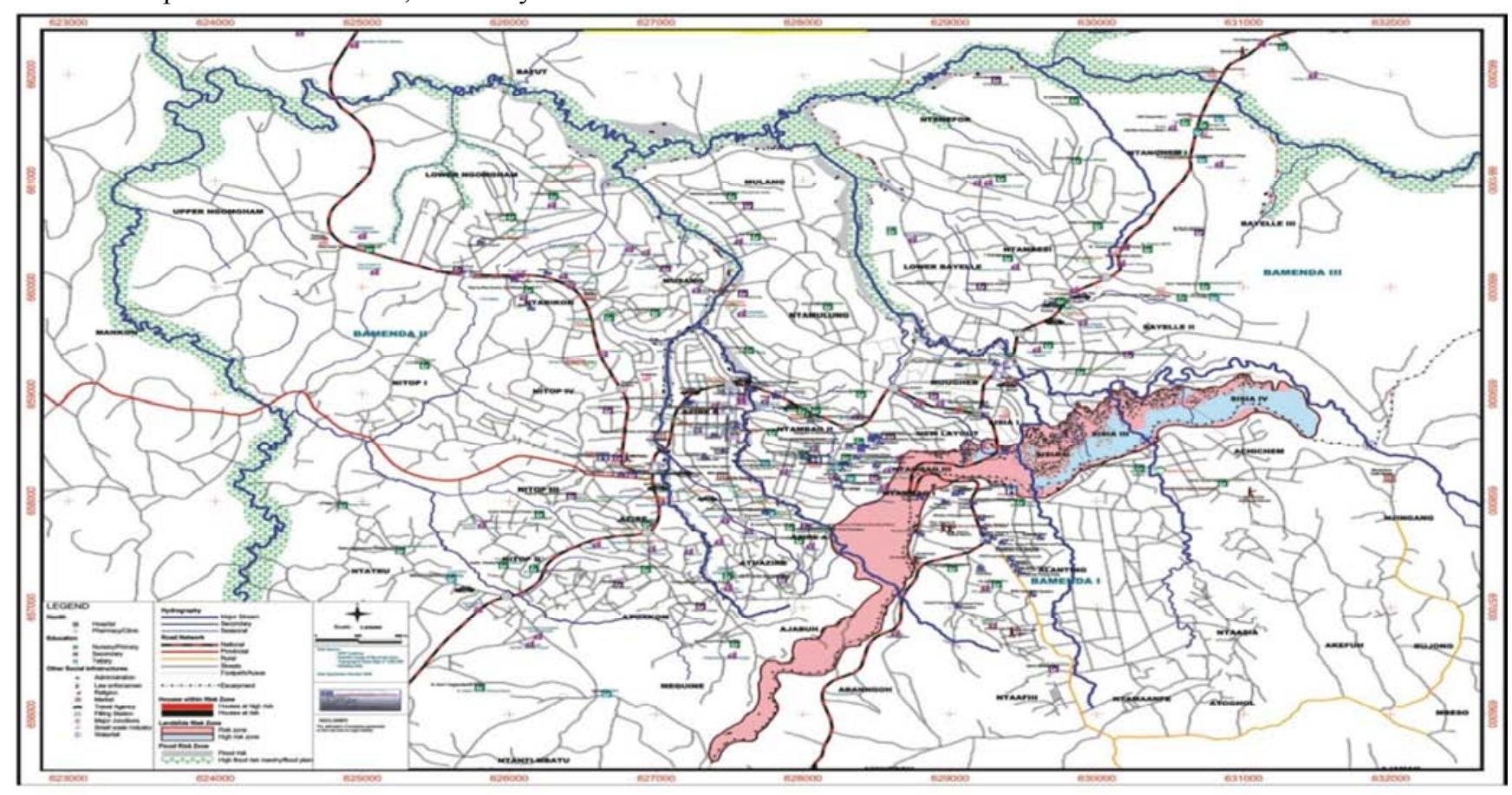

Source: GPS Field tracking

Figure 2. Spatial Distribution of Disaster Risk Zones in Bamenda.

Certain neighbourhoods have been tagged as 'high risk' zones due to their vulnerability to disaster risks [16]. These neighbourhoods which have been adequately delineated in this research fall within the council precincts of Bamenda I, Bamenda II and Bamenda III (Figure 2). Neighbourhoods prone to landslides include but not limited to the steep hill slopes of the broad Bamenda escarpment, the stretch along both sides covering parts of Sisia I to IV, Ntenifor I and II, New Layout, parts of Old Town, Atuazire, Ntagang to Abaingoh and the narrow stretch that extends to Mile-One at the Bamenda Up-Station. Neighbourhoods susceptible to floods include but not limited to the flood plains at Ntasin that cuts across Bamenda II and III council areas and stretch along the River Mezam and its tributaries, principally along Ntenefor (Below Foncha), New Layout, Mulang, Cow-boy Street, Ntamulung, Mulang Street 5, Lower Ngomgham, Small Mankon, Below Rendez-Vous, Atu-Azire, Nacho Street, Atuakom, Buea-Bamenda Street, Hospital Roundabout, Food Market, Old Town (Water-side), La Chance, Atuazire (Meta Quarter). Lower Bayelle and Church Centre). It also extends to the Bamenda III council area in neighbourhoods like Ntamuche, Afan, Nkwasi, Ntakekah, 
Ntenifor I and II, Menda, Ndamukong, Mofor Street, Cow Street.

Given the fact that environmental hazards are constant reminders at the door steps of the inhabitants of such neighbourhoods, the Government Delegate to the BCC, Vincent Ndumu, after the massive floods and landslides that ravaged Bamenda in July 2013 noted that: "The buildings which have so far been erected in these zones were erected in absolute defiance of the existing urban planning regulations as these neighbourhoods are considered high risk" [16]. As earlier noted, the high degree vulnerability of these neighbourhoods to disaster risks is masterminded by natural factors including; relief/topography, geology, geologic structure (the nature of the bed rock) as well as the degree of slope.

\subsection{Relief and Topography}

The relief and topography of Bamenda (Figure 3) has exposed the town to the caprices of disaster risks. Bamenda has two main relief units - the broad and steep escarpment (150m high and $7 \mathrm{~km}$ long) and the relatively low-lying zone (The Bamenda down-Town area). The escarpment, being a continuation of the Bamboutos Mountains in the West Region of Cameroon stretches from the South West (Ntahntig in Mbatu) radiating towards the centre and eastern portions separating Banjah from Mendankwe [17]. Naturally, such a broad/steep escarpment is a major hot spot for disaster risks by virtue of its extremely steep gradient, undulating nature and the precarious geologic structure composed of trachytes which are highly jointed.

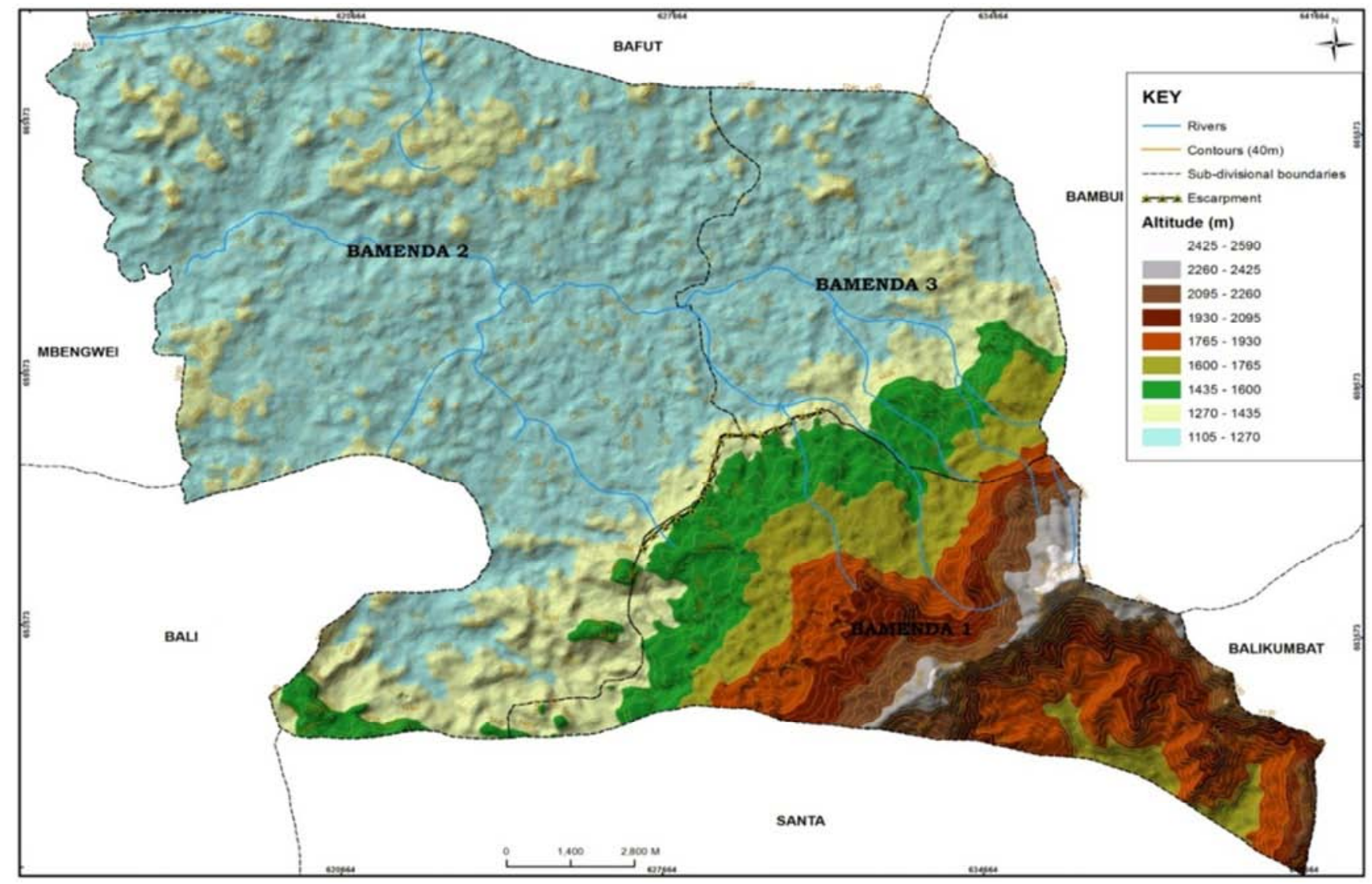

Source: Landsat ETM imagery 2015/Bamenda City Council

Figure 3. Digital elevation model for Bamenda.

As shown on Figure 3, the escarpment divides the town into two parts: the Up-Station zone (1270-2590m) above sea level and Bamenda Down Town zone (1105-1270m) above sea level. The Bamenda Down-town zone which stretches southwards away from the foot of the escarpment is the low lying zone where flood plains are found. Such a significant gradient difference between the Escarpment zone and Down Town $(1435 \mathrm{~m}-1105 \mathrm{~m}=330 \mathrm{~m})$ is eloquent testimony that the escarpment zone is extremely steep. Slope steepness is widely accepted as one of the most important determining factors of slope instability ([18-21]). The greater the angle of slope, the more susceptible the surface material is to mass wasting. According to [22], slopes of 0 to $25 \%$ are suitable for development though the degree of development varies from medium, moderate to low density while slopes above $25 \%$ are ideal for open space and certain recreational uses and not habitation (Table 1). 
Table 1. Percentage of Slope and Potential for development.

\begin{tabular}{ll}
\hline Degree of Slope in Percentages (\%) & Development Potential \\
\hline 0 to 3 & Generally Suitable for all development and uses. \\
3 to 8 & Suitable for medium density residential development, agriculture, industrial and institutional uses. \\
8 to 15 & Suitable for moderate to low-density residential development, but great care should be exercised in the location \\
of any commercial, industrial or institutional uses. \\
Above 25 & Only suitable for low-density residential, limited agricultural and recreational uses. \\
\hline
\end{tabular}

Source: Terry J. L (2008)

Field measurements and observations, however, revealed that the Bamenda Station escarpment is characterized by extremely steep slopes above $35 \%$ and in other cases may even attain $45 \%$. Such characteristics, in addition to the precarious geologic condition of the Bamenda escarpment makes it ecologically sensitive and fragile and, therefore, rife for landslides. This finding is corroborated by ([23]; [24] and [25]) who averred that under wet humid tropical climates as the case in Bamenda, slopes greater than $45 \%$ are known to fail. Despite this challenge, housing structures are being erected without reference to relevant information on the stability and ability of these slopes to carry such structures. Increase in housing construction reduces the shearing strength at the expense of shearing stress, which eventually reaches the point at which gravity overcomes friction. As shown on Figure 4, slopes of between 20 and $33^{\circ}$ on the Bamenda escarpment are carpeted by a dense network of residential structures.

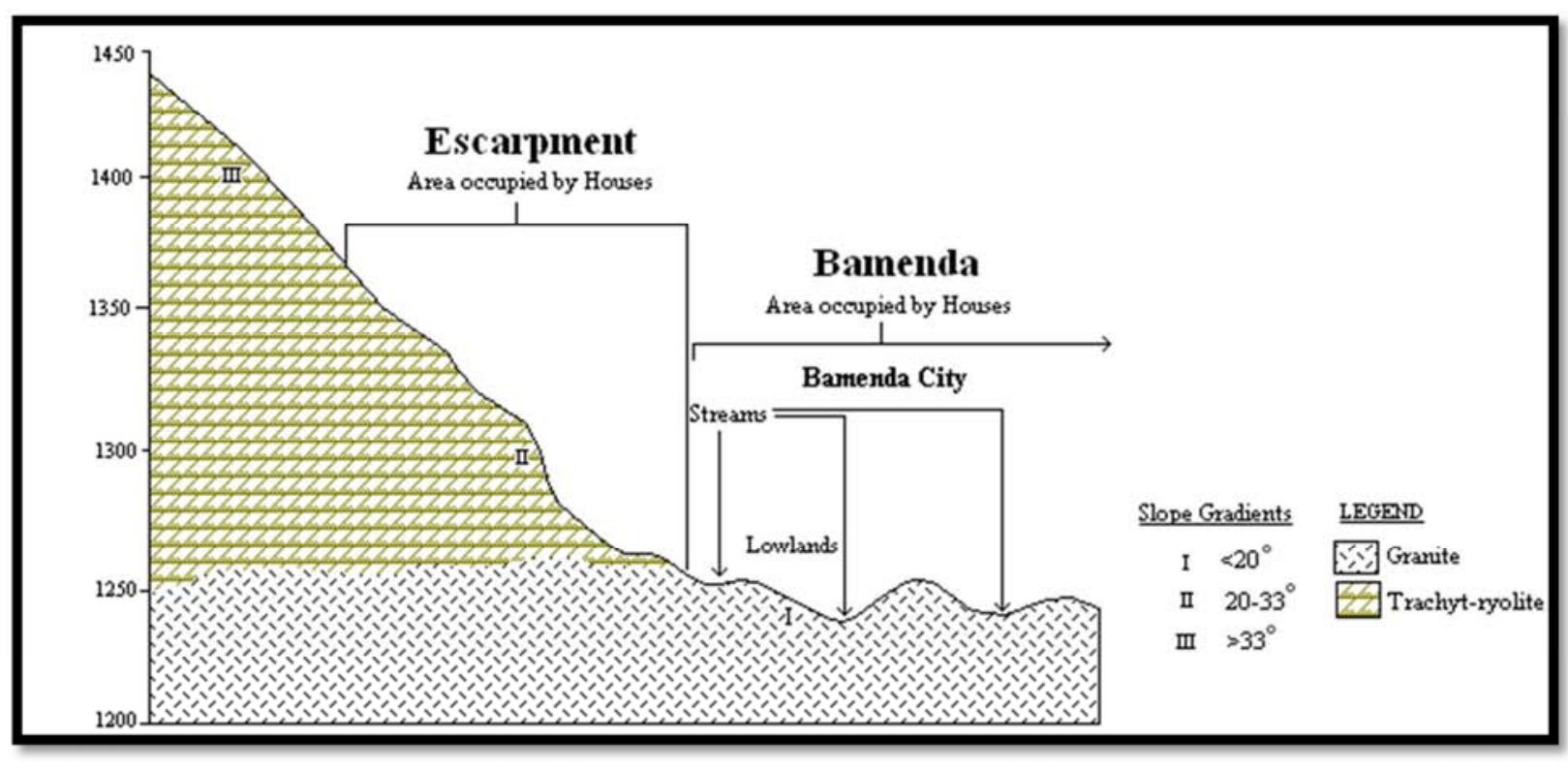

Figure 4. Typical Slope Gradient of the Bamenda Escarpment Zone.

Such a scenario does not augur well for environmental sustainability given the fact that the stability of a slope against sliding is cautioned by the relationship between the shear forces and the resistance to shear. The greater the intensity of settlement construction on a steep slope, the greater the shear stress and the more likely the mass failure process and vice versa. Besides, the greater the steepness of the slope, the more likely it is that rain will run off rather than infiltrate. Equally, the steeper the slope, the faster the water will travel with greater speed accompanied by a greater erosive power. That is why [26] described housing development on steep slopes as the case of the Bamenda escarpment like 'a disaster waiting to happen'.

\subsection{Geology}

The geology and geologic structure of Bamenda is a major disaster risk factor. The town is composed of two rock types; crystalline basement complex consisting of gneiss and granites and trachy-rhyolites with little protrusions (pockets) of dolerites and ignimbrites in a few isolated spots (Figure 5). Granites are resistant volcanic rocks formed when magma cools out of the earth's crust while trachyte are extrusive, fine grained igneous acidic volcanic rocks having a light grey colour with a rough surface when touched, reason why it is called trachyte ('trachys' means rough in Greek). From the geologic map of Bamenda (Figure 5) basement granites occupy approximately $3 / 4$ of entire surface area of the town and are concentrated in the Bamenda Down-Town zone while trachyte, dolerites and ignimbrites occupy approximately $1 / 4$ of the entire surface area of Bamenda and are concentrated on the escarpment. 


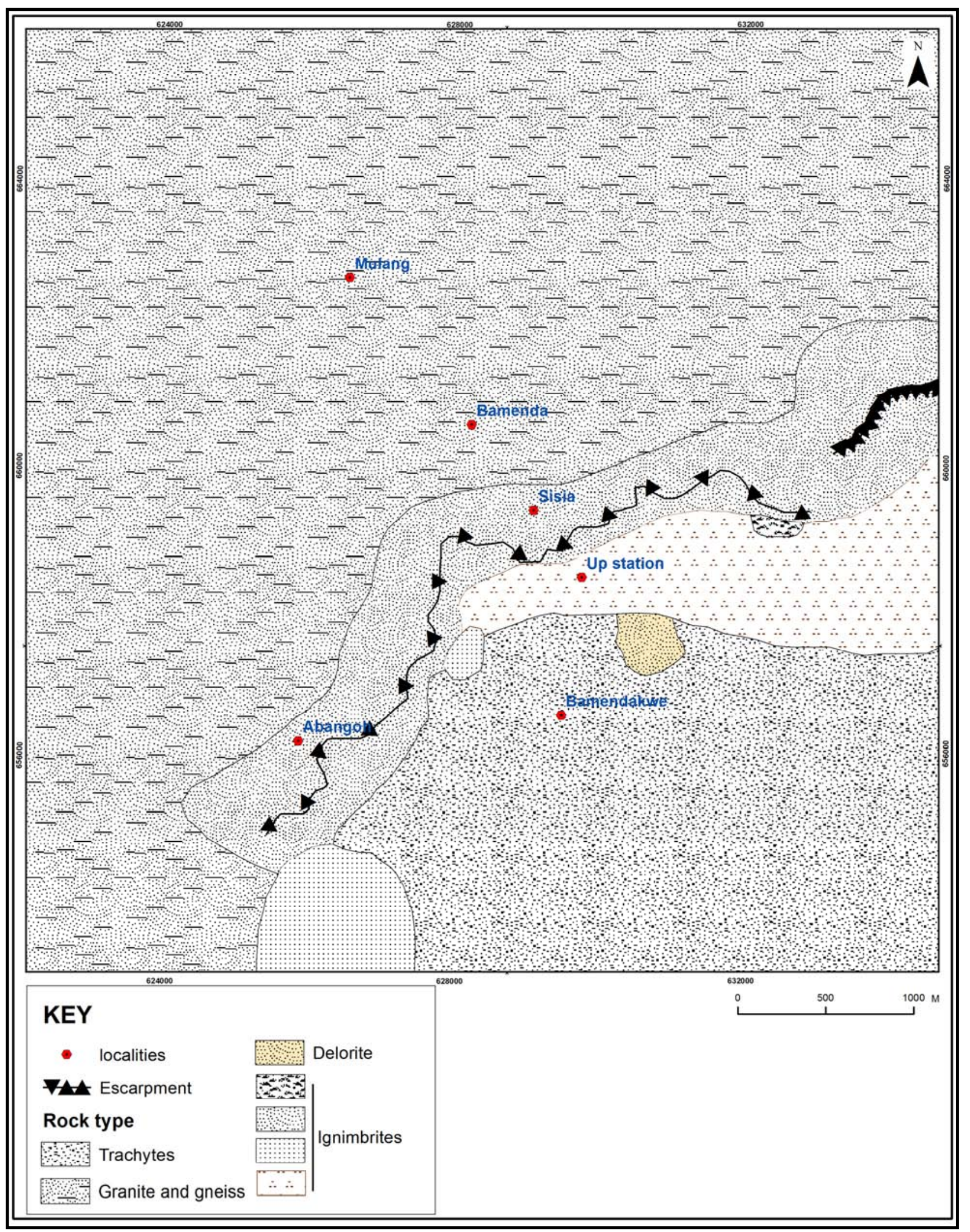

Source: Modified from Guedjo et al (2013)

Figure 5. Geology of Bamenda.

Granitic rocks are generally resistant and, therefore, pose no threat to disaster risks. However, the presence of trachyte is a major risk factor as weaknesses in its nature are inherent through the massive presence of vertical and horizontal joints and fractures which emanated from shrinkage/contraction during the cooling history of these volcanic rocks rendering 
them weak. In some cases, these joints are further widened and lubricated by the activities of plant roots. These joints have masterminded continuous infiltration of water into the rocks particularly in the course of the rainy season, overloading the slopes and by so doing, increasing the rate of deep chemical weathering. The rocks thus swells and weakens the bond between individual layers. This makes it easy for the materials above to slide. According to [27], igneous rocks containing feldspars produce clay minerals when weathered. The presence of clay minerals along some fractured zones in the rocks of the Bamenda Station escarpment thus supports the view that the constant occurrence of landslides on this mountainous back-bone is as a result of the absorption of water by these clay minerals.

\subsection{Decentralization and Disaster Risk Management in Cameroon and Bamenda}

From the above discussions so far, it is crystal clear that the natural setting of Bamenda is a major disaster risk factor. The mainstreaming of disaster risk management into urban development planning as an essential pre-cursor for sound environmental planning is a condition sine-qua-non. Disaster risk reduction are those activities undertaken by a community to "minimize exposure to hazards through the development and reliance on individual, social and institutional capabilities/capacities that can withstand potential loss or damage" [9].

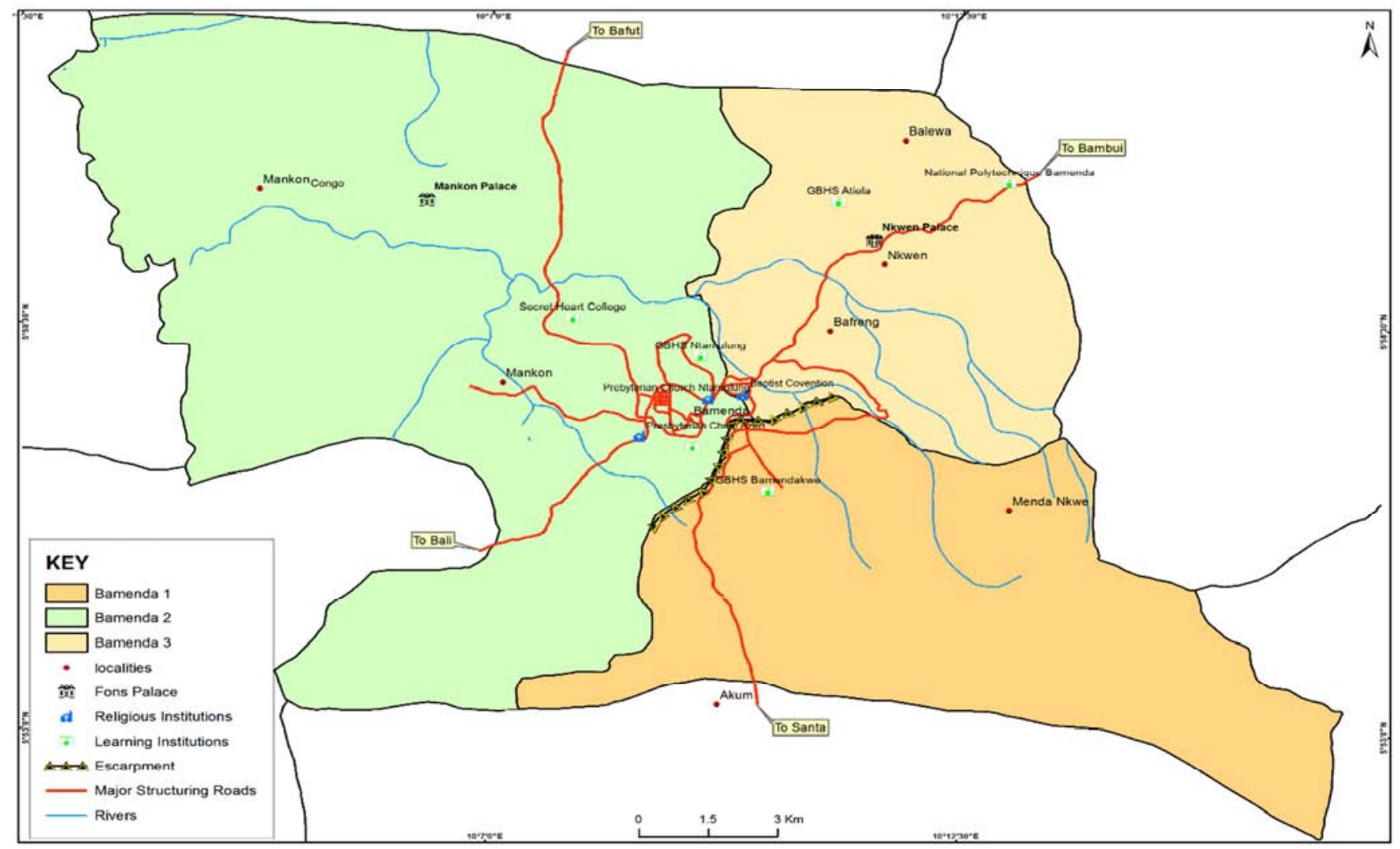

Source: Bamenda City Council and National Institute of Cartography (2017)

Figure 6. Sub Divisional Councils derived from Decentralisation.

To facilitate the mainstreaming of disaster risks into urban development planning, the government of Cameroon has channeled the management of disasters from the center to other tiers of government through decentralisation as a viable option. In respect of the compendium of the laws on decentralization, therefore, Decree No 2007/115 of April 13th 2007, balkanised the former Bamenda Urban Council (B.U.C) into three sub-divisional councils - Bamenda I (Mendankwe), Bamenda II (Mankon) and Bamenda III (Nkwen) as shown on Figure 6. The local councils established were expected to decongest the national government, act as a hedge against undue centralization, crack open the blockages of the inert central bureaucracy and give more direct access for the people to the government and the government to the people ([28]; [29]).

Based on this, Decree No. 2005/104 transformed the Directorate of Civil Protection in the former Ministry of Territorial Administration and Decentralisation (MINATD) to the Department of Disaster and Emergency Services (DDES). The DDES is responsible for organizing and coordinating civil protection activities throughout the country for both natural and human induced disasters and the governance of disaster risks through organs like the National Disaster Prevention and Management Program, the National Institute of Geological and Mining Research, the National Institute of Cartography, the National Civil Defense Council, the National Risk Observatory, the Emergency Medical Services and National Fires Service. From these organs, the local 
governments through councils have an important role to play with disaster management functions conferred upon them by the legislative and administrative instruments governing local government in Cameroon. According to this, local institutions are expected to have adequate organizational capacities and plans in place to address the risks and consequences of disasters. By allowing local communities and regional entities to manage their own affairs through facilitating closer contacts between central and local authorities, effective systems of local governance enable responses to people's needs and priorities to be heard, thereby ensuring that government interventions meet a variety of needs when it comes into disaster risk reduction/management.

The local councils created, however, appeared to have had very minimal positive impact on disaster risk management in Bamenda because significant gaps, remain in communication and information flows in crisis management [30] supporting the view by [7] that government officials and citizens have paid little attention to preventive measures or mitigation strategies before a disaster actually strikes. That is why in the wake of its practical implementation, very shallow and little deep-seated changes have been experienced in the domain of environmental sanity as disaster risk management gains that have been achieved is nothing to go by and, therefore, not different from the pre-existing statusquo (centralization) due to some inherent challenges for environmental management in developing and transitional countries associated with disaster risks [31] (Table 2). According to Table 2, tentative challenges for environmental management in developing countries and associated problems with disaster risks includes weak rule of law, high corruption, lack of participation, weak environmental authorities and incoherent and uncoordinated policies and gaps in tasks and responsibilities.

Table 2. Typical Challenges for Environmental Management in Developing and Transitional Countries and Associated Problems with Disaster Risks.

\begin{tabular}{ll}
\hline Tentative Challenge & Associated Problems and Risks \\
\hline Environmental law is low priority & -Lack of human and financial resources \\
& -Low support from political leaders \\
$\begin{array}{l}\text { Weak understanding of environment-poverty } \\
\text { development links }\end{array}$ & -Environment is perceived as a barrier to other development objectives (e.g. growth, job \\
& $\begin{array}{l}\text { opportunities, etc) } \\
\text {-Uninformed decisions may obstruct sustainable development }\end{array}$ \\
Weak rule of law, high corruption risk, low & -Implementation of environmental legislation is likely limited \\
transparency and lack of participation & - Natural resource rents not used for common good \\
& -Voice and rights of vulnerable groups are not respected \\
Weak environmental authorities primarily financed & -Lack of information obstructs accountability \\
through external, project based, fund raising & -Project proposals based in international rather than national priorities \\
Cross-sectoral coordination low & -Project management rather than strategic governance \\
\hline
\end{tabular}

Source: Gunilla et al (2012) based on OCED (2012)

The above challenges can be narrowed and configured within the disaster risk management sector in Bamenda to include problems which are largely due to inadequate local capacities, limited grassroots participation and conflicts of interest amongst urban management stakeholders. It is on the strength of these controversies that this section questions the comprehensiveness of the competencies devolved to local actors in a bid to explore the effectiveness of decentralization as a response mechanism for disaster risk management in Bamenda.

\subsection{Inadequate Local Capacities / Lack of Staff Skilled in Disaster Risk Management}

The effectiveness of decentralization as a response mechanism for disaster risk cannot be effectively understood if due consideration is not given to the capacities of local actors as heated debate on whether the central government/local government sectors have the capacity to manage disaster risks is common placed. Local administrative capacity in the management of disaster risks is considered grossly inadequate because the design of environmental legislation on disaster risk does not provide succinct guidelines, resources, and incentives to fortify local capacity. For example, in Bamenda I, II and III council areas, limited administrative capacity has constrained the decentralization of management functions relating to risk management. This is even severe and aggravated by the fact that the central government also lacks the capacity to manage disaster risks. If the appropriate requirements for disaster risk management were assigned to each level of government according to the information required for them to perform their functions, local capacity would probably not be an issue.

Besides, there is sheer lack of professionalism in technical aspects in environmental management as well as deficiencies in information technology provision on environmental issues like Geographical Information Systems (GIS), Remote Sensing (RS)) and Disaster Management (DM) for sustainable urban development [32]. Equally, existing maps on environmentally robust areas which can withstand urban development and environmentally sensitive areas which cannot withstand development and thus prone to disaster risks are old, outdated and, therefore, not conducive as an information base for the identification and integration of disaster risk management into urban development planning. This means pre-existing spatial data or geo-information in the form of maps, plans, aerial photographs, satellite images which form the base on which urban environmental planning in relation to disaster risks is undertaken are poorly updated and put into use [32]. Based on this, no realistic and 
sustainable disaster risk reduction strategy can be done without an adequate spatial information base as it becomes difficult to plan, subdivide, develop and provide appropriately for infrastructure, utilities and services in order to reduce disaster risks. Based on this, it is ostensibly clear that the various stakeholders are unable to make the requisite impacts as the quality and quantity of personnel to carry out and implement sound environmental policies and policies is constrained.

\subsection{Limited Grassroots Participation}

Decentralizing urban governance as a strategy for disaster risk reduction/ management ensures that people in the grass roots/community must have a voice, interest and ownership in the development of their land. This is because cultivating a thorough understanding of the complex realities on the ground is the key to disaster risk management as greater community involvement does not only minimize the chances of conflicts that have been a setback to major environmental projects but enhances environmental monitoring, management and capacity building of local community members. This, therefore, raises the question as to whether the decentralisation of environmental management in Bamenda in relation to disaster risks is 'participatory' or just 'administrative'.

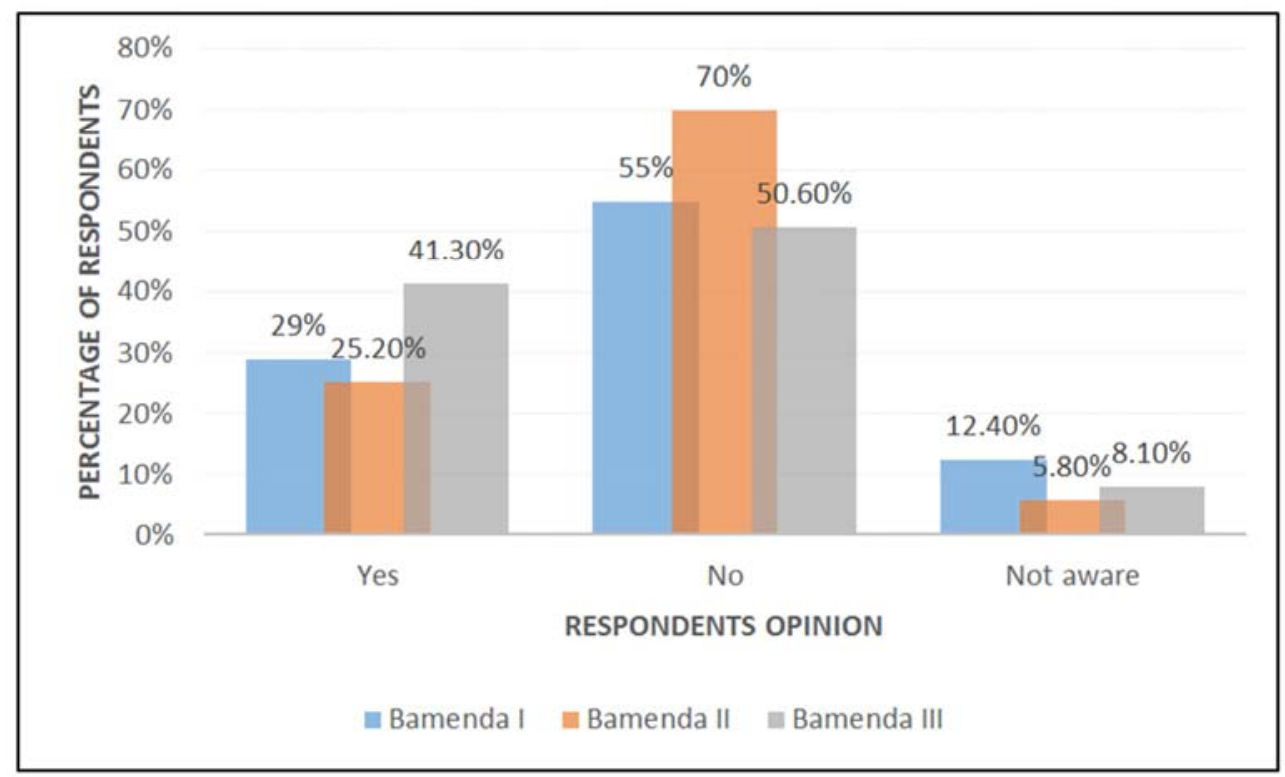

Source: Field Survey (2018)

Figure 7. Cumulative Responses on the Inclusion of the Community and other Management Stakeholders in Decentralisation Issues.

Field responses (Figure 7), however, showed contrasting discrepancies on their perceptions towards the inclusion of the community and other stakeholders in matters of urban environmental management in this era of decentralisation. $55 \%, 70 \%$ and $50.6 \%$ of the population in Bamenda I, II and III respectively were unanimous that the opinion of the community (citizens), some government institutions and the various sub divisional councils were not considered in development issues pertaining to the urban environment [32]. They lamented that what obtains in the management of the Bamenda urban space is the top-bottom approach. This is in direct contravention of Agenda 21, Chapter 21 and Principle 10 of the Rio Declaration which states that: "Environmental issues are best handled with the participation of all concerned citizens, on a relevant level". According to the Director of Urban Development in the B.C.C; "the non-involvement of citizens and local stakeholders charged with urban development in the execution of development projects of top environmental such as disaster risk reduction stands tall". In such a circumstance, success is far from being achieved as exogenous stakeholders conceive and implement disaster risks reduction projects through the top-bottom than bottomup (participatory) and by so doing, fall short of site specific environmental realities, aspirations and needs of the people at the bottom. That is why disaster risk management in Bamenda is still basically "for the people" rather than being "with the people". From such startling revelations, it is evident that a glaring disjuncture exists between the objectives of decentralization and disaster risk management in Bamenda.

Besides, the structure of disaster management in Cameroon, is not responsive to disaster risk management/reduction because the devolution of disaster risk management powers (Table 3 ) is bureaucratic and hierarchic in nature. As shown on Table 3, powers move from the presidency of the republic to the ministerial departments, down to the regional governors and delegations, and further down to the divisional officers and divisional delegations, and ending with the local civil and municipal administrators. The implication of such a management strategy is that disaster risk management issues are bound to be delayed, in addition to the fact that administrative bottlenecks are 
inherent. From the above description, it glaring that practically, the disaster management strategy of the Cameroon government is centered on providing post disaster relief and rehabilitation (reactive) rather than being proactive and preventive.

Table 3. Structure of Disaster Management in Cameroon.

\begin{tabular}{ll}
\hline Government Organ & Duties \\
\hline $\begin{array}{l}\text { 1. Presidency of the Republic (National Commission on Civil Protection } \\
\text { NCCP), }\end{array}$ & $\begin{array}{l}\text { Defines policies, sets up the NCCP; harnesses national and international } \\
\text { relief efforts } \\
\text { 2. Ministry of Territorial administration and decentralization MINATD } \\
\text { (DDES) }\end{array}$ \\
$\begin{array}{ll}\text { 3. Regional Governors (Economic and Social Service; Regional Delegation } \\
\text { disaster and emergency fund }\end{array}$ \\
$\begin{array}{ll}\text { Cocial Affairs) } & \text { Supervisory authority at the divisional level, sets up local crisis commission } \\
\text { 4. Senior Divisional Officers (Divisional Delegation of Social Affairs) } & \text { with the approval of the Regional Governor } \\
\text { 5. Sub divisional Officers/Municipal Councils/Local NGOs, and so on } & \text { Implement relief efforts }\end{array}$ \\
\hline
\end{tabular}

This is because it is a "top down" hierarchical structure which puts more emphasis on disaster response than prevention and mitigation. This is even worsened by the fact that institutional arrangements and distribution of powers between central and local governments have sometimes been ambiguous, thereby undermining the ability of local governments to apply environmental powers for sustained disaster risk outcomes as the control over the necessary financial and human resources have remained largely centralized.

Although the current civil protection structure (Table 3) seems to have been decentralized by involving municipalities and divisional as well as sub-divisional delegations of the concerned ministries, the devolution of authority to lower administrative levels is limited in practice [33]. For example, Law No. 2004/018 of 22 July 2004 stipulates that municipal councils are responsible for such tasks as organizing and coordinating relief operations [34]. But they must await authorization and approval from higher administrative levels, the immediate one being the Senior Divisional Officer. As the local authorities await authorization to come down the chain of command, the disaster continues to claim victims.

In actual fact, Cameroon lacks a national disaster management structure and a national platform for disaster reduction. This is because disaster related activities are lumped together with other civil protection responsibilities of the Ministry of Territorial Administration and Decentralization (MINATD) despite the country's commitment to the Hyogo Framework for Action 2005-2015. Besides, while decentralization tacitly endorses civil society as important agents in the overall success in urban management in Cameroon and Bamenda in particular, there are no formal structures designed to incorporate them in the decision making relating to disaster risk management. This disjuncture between the stated objectives of decentralization and the actual exclusion of elements of civil society and NonGovernmental Organisations have rendered decentralization as an inefficient response mechanism for disaster risk reduction in Bamenda. That is why the level of awareness and action has not been commensurate with the state of disaster risk in Bamenda today; as such the urban environment continues to deteriorate due to an increase in environmental problems.

\subsection{Conflicts of Interest Amongst Urban Management Stakeholders}

Local governments are supposed to take decisions that help reduce disaster risks. This has, however, not been the case in Bamenda due to conflicts of interest. Conflict and overlapping responsibilities between government agents (The Governors, Senior Divisional and Divisional Officers) and other institutions of governance (Bamenda City Council, the Ministries of Territorial Administration, Housing and Urban Development, Surveys, State Property and Land Tenure) and the different Municipalities (Bamenda I, Bamenda II and Bamenda III) charged with the management of the Bamenda urban space has also been a pre-occupying issue. The national government has exercised strong control over the local government through the appointment of a top bureaucrats such as a Government Delegate in Bamenda to lord over mayors who are duely elected the by the grassroots through an opposition party. This has made decentralization as a response mechanism for disaster risk reduction more of a theory than practice, creating conflicts of authority between officials within these two different political spectrums as the government Delegate claims he was appointed by the head of state and remain accountable to him rather than to the local electorates. This interventionist and obstructionist role of state imposed officials in Bamenda and other cities in Cameroon [35] has led to heightened conflicts at the level of urban management.

According to a Counsellor at Ntamulung in Bamenda II sub division; "the recentralization of decentralized functions in Bamenda under the canopy of decentralization is glaring and thus a challenge to disaster risks reduction because it stifles and hampers the ability to configure urgent environmental issues of utmost importance". This is due to the continuous tendency of the central government through the BCC to interfere in purely local matters despite the existence of decentralisation. This is because when two opposing views come into contact, there is often an osmotic tendency for the stronger one to absorb the weaker one, or at least influence it much more than it is itself influenced by the weaker one. This, according to a field informant at Ntamulung is synonymous to 'selling a goat to a buyer and 
at the same time holding back the rope in order not to let go of that goat.' Equally, the management of disaster risks through the issue of urban planning instruments (land titles and building permits) is counter-productive given the fact that the creation of the Bamenda City Council has diluted the influence of sub divisional councils, making the transition of government's role from "doer" to "regulator" difficult. Such a 'recentralized' system of governance under the mirror of decentralization is inflexible to respond to disaster risks issues with a commensurate speed and agility as they must first be validated at the level of the B.C.C. The authorities of the mayors through the Sub Divisional Councils, thus remain weak as B.C.C continues to exercise tremendous authority in a highly centralized manner giving little room for the local councils to make strategic decisions on disaster risk reduction. This is because of their inability to shoulder broad responsibilities due mainly to lack of complete autonomy from the central government through the B.C.C.

\section{Conclusion and Recommendations}

Decentralization as a tool for disaster risk management may be well intentioned in Cameroon. However, the conditions necessary for its effective take-off have remained a text book concept. This paper thus argues that even though decentralization represents a very ambitious model in its design, problems of fit with other policy objectives, especially with those of the central government, have limited the possibilities for its sustainability as a response mechanism for disaster risk management. This missing link is beset and partly catalyzed by deep institutional and regulatory lapses in the manifestation of decentralisation, poor policy implementation and enforcement mechanisms relating to town planning instruments, inefficiencies and bureaucracy subjecting the entire set up to the caprices of disaster risks. Despite efforts made by the authorities charged with the management of the Bamenda urban space to contain such stalemates, there is uncontrolled urban sprawl encroaching into disaster risk zones. Urban management practices in Bamenda have thus failed to sustainably infiltrate the concept of decentralization into the discourse and dynamics of disaster risk management. That is why isolated pockets of unplanned urban spaces which are identification hall marks of future disasters are glaring in Bamenda given the fact that necessity to mainstream disaster risk reduction into urban development planning is not yet an underlying principle of Cameroon's disaster management framework.

Drawing inspirations on evidence from the World Bank's operational work, the paper suggests the need for a stronger focus on institutions in designing decentralization policies for disaster risk reduction. This broader agenda suggests an enhanced focus on good local governance whose building blocks revolve along the essential pre cursos of good governance (citizen participation, partnerships among key actors at the local level, capacity of local actors across all sectors to monitor compliance with comprehensive rules and regulations, multiple flows of information and institutions of accountability). Besides, the need for the central government to devolve effective environmental powers to local governments, for local governments to increase their revenue raising capacity in order to achieve greater financial autonomy is not left out.

\section{References}

[1] Wallis, L. (1999). "Decentralisation in Lesotho" in Reddy, P. S. (ed) Local Government, Democratization and Development: A Review of Southern African Region. London: Juta \& Co.

[2] Robertson, W. (2016). "Overview of Decentralisation Worldwide: A Stepping Stone to Improved Governance and Human Development," New York, United Nations.

[3] Shale V. R (2004). Decentralization, Development and Conflict: Challenges Awaiting Local Authorities in Lesotho. The Electoral Institute of Southern Africa.

[4] World Vision (2015). Building Urban Resilience through Disaster Risk Reduction in Asia and Pacific. Priorities, Good Practices and Lessons Learnt.

[5] World Bank (2015). East Asia's Changing Landscape: Measuring a Decade of Spatial Growth. Washington D, C. World Bank.

[6] Nyangabyaki B (2003). Environmental Governance in Africa Decentralization, Politics and Environment in Uganda. Working Paper Series. World Resources Institute. Institutions and Governance Program, Washington DC.

[7] Yooil, JOO, Yu-Min, \& WON, Soh-Yeon. (2015). Decentralization and collaborative disaster governance. Habitat International, 52, 50-56. Available at: htp://ink.library.smu.edu.sg/soss_research/1850

[8] UNDP (2004). Human Development Report 2015. A framework for Human Development. United Nations Organisation, New York.

[9] UN/ISDR, (2002). United Nations International Strategy for Disaster Reduction Living with risk: A global review of disaster reduction initiatives. The Secretariat of the International Strategy for Disaster Reduction (UN/ISDR), United Nations, Geneva, Switzerland, 382 pp. (http://www.unisdr.org)

[10] SALGA (2017). South Africa Local Government Association: Risk Management Framework.

[11] Ndi R. A, Kometa S. S and Lambi C. M (2017). Controversies in Building Permit Acquisition as an Environmental Deterrent to Physical Development Planning in Bamenda. International Journal of Resource and Environmental Management. Volume 2, Number 1. The Environmental and Social Research Center, Unique Printing and Publishing House, Bamenda. Pp 25-38.

[12] Afangang and Nkwemoh (2017). Spatial Modelling of Landslide Susceptibility Using Logistic Regression Model in the Bamenda Escarpment Zone, NW Cameroon. International Journal of Innovative Research and Development. Vol 6, No 12 . 
[13] Tiafack, O., \& Mbon, A. M. (2017). Urban Growth and Front Development on Risk Zones: GIS Application for Mapping of Impacts on Yaounde North Western Highlands, Cameroon. Current Urban Studies, 5, 217- 235. https://doi.org/10.4236/cus.2017.52013.

[14] Nkwemoh, C. A., Mesmin, T., \& Afungang, R. N. (2017). The Impact of Urbanisation on the Vegetation of Yaounde, Cameroon. International Journal of Innovation Research and Development, 6, 6-18.

[15] The Bamenda Master Plan (2013-2027).

[16] The Chronicle Newspaper (2009). No 141, July 2009.

[17] Guedjeo, C., Kagou, D. (2013). Natural Hazards along the Bamenda Escarpment and its Environs: The case of Landslide, Rock fall and Flood risks. Global Advanced Research Journal of Geology and Mining Vol. 2. http://garj.org/garjgmr/index.htm. Global Advanced Research Journals. Accessed on 11/11/2013.

[18] Dietrich, W., Montgomery, D., (1998). A digital terrain model for mapping shallow landslide potential. National Council of the Paper Industry for Air and Stream Improvement (NCASI) Technical Report: pp. 26.

[19] Bateira, C., (2010). Evaluation of natural susceptibility in the north of Portugal. Analysis and territorial management. Prospectiva e Planeamento 17, 15-32.

[20] Soeters, R., van Westen. (1996). Slope instability recognition, analysis and zonation. In: Turner K, Schuster R (eds.), Landslides investigation and mitigation. National Academy Press, Washington, pp 129-177.

[21] Montgomery, D. R., Dietrich, W. E., (1994). A physically based model for the Topographic control on shallow landsliding. Water Resource Research 30(4), 1153-1171.

[22] Terry, J. L (2008): Steep Slopes; Guide/Regulations. Lehigh Valley Planning Commission. Longman publishers, London.

[23] Lambi, C. M. (1998). The Matomb Slope Instability Hazard on the Yaounde-Douala Highway, Cameroon, West Africa. Cameroon Geographical Review, Faculty of Letters and Social Sciences, University of Yaounde I, Volume XIII, Number 2, pp 1-9

[24] Lambi C. M., C. G Kometa and J. N. Kimengsi (2012). Reflections on Landslide Hazard in Limbe Municipality, South West Region of Cameroon. In Lambi C. M (ed): African Journal of Social Sciences, Volume 3, Number 3. Unique Printers, Bamenda.
[25] Brochu, M. (1981). Methode d'emraiement de l'erosion des Coupes des Voies de Communication en Milieu Tropicale. Cahiers Géologiques, No 97, Universitaire P. M. Curie 4 P1, Jussieu, 75005, Paris, pp388-389.

[26] Whitten, D. and Brooks. R. (1972). Dictionary of Geology. pp44 \& 162 ,

[27] Mawhood. P. (1993). Local Government in the Third World, Experience of Decentralization in Tropical Africa, $2^{\text {nd }}$ edition, Pretoria: Africa Institute of South Africa.

[28] Abangma, J. (2009). "Fundamental Autonomy and the Performance of Communes in Cameroon: Local Government for the People", African Journal of Contemporary Issues, Vol. 9, No. 1:1-60.

[29] United Nations Publication (2005). Decentralization: Poverty Reduction, Empowerment and Participation. Department of Economic and Social Affairs. United Nations, New York.

[30] Lee, M., Richard, G. and Henry, B. (2017), "Blaming active volcanoes or active volcanic blame?" Volcanic Crisis Communication and Blame Management in the Cameroon, Springer, Berlin, Heidelberg.

[31] Gunilla W, Daniel S., Martin S, Olof D., Anders E (2012). The role of governance for improved environmental outcomes Perspectives for developing countries and countries in transition. Swedish Environmental Proctection Agency.

[32] Ndi R. A, Kometa SS \& Lambi C. M (2017). The Efficiency of Urban Planning Regulations on Environmental Management in Bamenda, North West Cameroon. Journal of Environment and Earth Science. Vol. 7, No. 10. Pp 104-113.

[33] Bang, H. N., (2013). Governance of Disaster Risk Reduction in Cameroon: The Need to Empower Local Government. Jàmbá: Journal of Disaster Risk Studies Vol 5, No 2, pp.10 http://dx.doi.org/10.4102/jamba.v5i2.77. Accessed on $15 / 06 / 2016$

[34] Roland Ndille and Johannes A. Belle (2014). Managing the Limbe Floods: Considerations for Disaster Risk Reduction in Cameroon. Int J Disaster Risk Sci (2014) 5:147-156.

[35] Mbuagbo, O. T and Akoko, R. M (2004). Roll-Back: Democratization and Social Fragmentation in Cameroon. Nordic Journal of African Studies 13(3):1-12. 